\title{
Mycorrhizal infection indicates the suitability of different management treatments for nature conservation in calcareous grassland
}

\author{
Markus Bernhardt-Römermann • Hans-Jörg Brauckmann • \\ Gabriele Broll • Karl-Friedrich Schreiber • \\ Peter Poschlod
}

Received: 25 March 2009/Accepted: 24 September 2009/Published online: 13 October 2009

(C) The Author(s) 2009. This article is published with open access at Springerlink.com

\begin{abstract}
The vegetation composition of calcareous grasslands in Central Europe is mainly determined by the applied management treatments and the nutrient status of the ecosystems, but these factors cannot clearly be separated. Recently several authors reported a shift in growthlimiting plant nutrients from nitrogen to phosphate. Therefore, we tested the interaction between management and plant available phosphate in a long-term experiment in Southern Germany with different management treatments applied to calcareous grassland. We measured mycorrhization rates, which are assumed to be high at low phosphate availability, to explore the interaction between management, phosphate availability and vegetation composition. By correlating mycorrhization rates to vegetation and soil data we found that treatments involving nutrient
\end{abstract}

Responsible editor: Sonja Wipf.

M. Bernhardt-Römermann ( $\square)$

Department Silviculture and Forest Ecology of the Temperate

Zones, Faculty of Forest Sciences and Forest Ecology,

Georg-August-University Göttingen, Büsgenweg 1,

37077 Göttingen, Germany

e-mail: Markus.Bernhardt@forst.uni-goettingen.de

H.-J. Brauckmann · G. Broll

Department of Geoecology and Agricultural Ecology,

Institute for Spatial Analysis and Planning in Areas of Intensive

Agriculture, University of Vechta, P.O. Box 1553,

49364 Vechta, Germany

K.-F. Schreiber

Institute of Landscape Ecology, University of Münster, 48149 Münster, Germany

\section{P. Poschlod}

Institute of Botany, Faculty of Biology and Preclinical Medicine, University of Regensburg, 93040 Regensburg, Germany removal show a greater degree of mycorrhization than treatments leading to nutrient enrichment. According to decreasing suitability for grassland conservation, the six different management treatments could be ranked as mowing, followed by mulching (twice a year, once a year and every second year), burning and undisturbed succession. It was shown, that mycorrhizal infection rates (1) can be used to evaluate different management treatments for their suitability to conserve the initial vegetation composition, and (2) may provide information about the processes of adaptation to the current management, namely to differences in plant available phosphate. However, as discussed for the undisturbed succession treatment, it might not be sufficient to look at the degree of mycorrhization only. These are related to phosphate availability, but to detect adaptation processes to management, the degree of mycorrhization should be analysed together with plant's internal nutrient relocation patterns.

Keywords Mulching - Nutrient limitation - Phosphate · Undisturbed succession

Zusammenfassung Die typische Vegetationszusammensetzung von Kalkmagerrasen in Mitteleuropa wird vor allem durch Unterschiede im Management und der Nährstoffversorgung bestimmt, wobei sich allerdings die Auswirkungen dieser zwei Faktoren nicht klar abgrenzen lassen. In jüngeren Publikationen wird berichtet, dass Stickstoff als wachstumslimitierender Faktor zunehmend von Phosphat abgelöst wird. Daher wurden in dem vorliegenden Artikel die Auswirkungen verschiedener Managementvarianten auf die Erhaltung der typischen Vegetationszusammensetzung und -struktur sowie auf den Phosphathaushalt untersucht. Hierzu wurden die Mykorrhizierungsraten von drei Pflanzenarten verglichen. 
Die Mykorrhizierungsraten sind eng mit der Fähigkeit zur Phosphataufnahme verknüpft: sie sind hoch bei geringer Phosphat-Verfügbarkeit. Die Mykorrhizierungsraten wurden mit Vegetations- und Bodendaten korreliert und ein positiver Zusammenhang zwischen Managementvarianten, die zu einem Nährstoffentzug (vor allem Phosphat) führten und den Mykorrhizierungsraten gefunden. So war es möglich die sechs Managementvarianten nach Ihrer Eignung für die Erhaltung der ursprünglichen Vegetation zu bewerten: Mähen, gefolgt von Mulchen (zweimal jährlich, einmal jährlich, alle zwei Jahre), Brennen und freier Sukzession.

Mykorrhizierungsraten können genutzt werden um (1) verschiedene Managementvarianten hinsichtlich Ihrer Eignung zur Erhaltung der ursprünglichen Vegetation zu bewerten, und (2) Informationen über die den Vegetationsveränderungen und Anpassungen zugrunde liegenden Prozesse, also die Unterschiede in der Phosphatverfügbarkeit, zu erlangen. Allerdings wurde am Beispiel der Sukzession gezeigt, dass neben den Mykorrhizierungsraten auch Prozesse der pflanzeninternen Nährstoffverlagerung eine Rolle spielen. Um die Bedeutung von Phosphat für die Vegetationsentwicklung zu bewerten, sollten Mykorhizierungsgrade und Nährstoffverlagerungsprozesse gemeinsam analysiert werden.

\section{Introduction}

Human land-use is one of the most important drivers influencing the vegetation composition of non-alpine grasslands. In the cultural landscape of central Europe human impacts are of particular importance as the potential natural vegetation would be forest (Bohn and Neuhäusl 2004). Since the beginning of agriculture the landscape was opened and in many places grassland ecosystems evolved due to extensive sheep or cattle grazing (Küster 1996). These semi-natural grasslands are of major importance for nature conservation as they often harbour a diverse flora and fauna containing rare species (WallisDeVries et al. 2002). However, these species assemblages are specifically adapted to management and therefore strongly endangered by changes in management (Quétier et al. 2007). Since the beginning of the last century traditional land-use practices were often altered due to economical reasons since agriculture was intensified or sites were abandoned (Watkinson and Ormerod 2001; Poschlod and WallisDeVries 2002; Poschlod et al. 2005). In addition to changes in management, the nutrient status of an ecosystem is important, as it is well known that vegetation composition of grasslands is related to nutrient availability (Garcia 1992; Myklestad 2004; Schmidt 2006b).
To keep grassland sites in good ecological conditions, practical nature conservation needs management treatments that mimic traditional land-use at low costs while being suitable to maintain the characteristic species composition. A recent EU-Directive (CC: Cross Compliance) even regulates the 'minimal' management for this goal: it specifies that either mulching once a year (=mowing without removal of the phytomass) or alternatively mowing every second year must be applied. As shown by several studies (Moog et al. 2002; Kleijn and Sutherland 2003; Römermann et al. in press) at least for dry grasslands the proposed management treatments do not seem to be adequate. Therefore, in the current study we aim at comparing different management treatments to evaluate their value for nature conservation goals. For this comparison we used one site (St. Johann) of the fallow-land experiments BadenWürttemberg, where plots with different management practices like mulching, mowing, grazing, burning and natural succession exist since 1975. Such management treatments have different effects on vegetation composition (Schreiber 1995; Moog et al. 2002; Kahmen 2004; Schreiber et al. 2009a) as well as on soil nutrient contents (Werth et al. 2005; Lorenzo et al. 2007).

In many studies nitrogen was found to be the growthlimiting factor in calcareous grasslands (e.g. Willems et al. 1993; Neitzke 2001), but today nearly every ecosystem in central Europe is highly affected by nitrogen deposition (Bobbink and Roelofs 1995); for most ecosystems it thus seems unlikely that plant growth is any longer limited by nitrogen. Consequently, different authors stressed the importance of phosphate (or the co-limitation of nitrogen and phosphate) for vegetation development in semi-dry grasslands (Morecroft et al. 1994; Wilson et al. 1995; Grime et al. 2000; Köhler et al. 2001; Carroll et al. 2003). However, it is difficult to estimate the effect of phosphate as a growth limiting factor from simple soil analyses, as plants may take up phosphate in very low concentrations with the help of mycorrhizal fungi. As proposed by Titus and Leps (2000), one way of estimating the extent, to which an ecosystem is limited by phosphate is the analysis of the degree of mycorrhization. Mycorrhization generally enhances phosphorus uptake (Koide 1991; Mullen and Schmidt 1993) because mycorrhizal fungi can take up phosphorus in lower concentrations than plant roots (Smith and Read 1997).

As already mentioned, vegetation composition and nutrient availability are connected: the aim of a suitable management treatment for nature conservation should be a reduction (or at least not an increase) of plant growth limiting soil nutrients. Thus we assume greatest mycorrhizal infection rates for those treatments with greatest potential for maintaining initial vegetation composition. Based on the results of Titus and Leps (2000) that in 
ecosystems with low phosphate supply mycorrhizal infection rates are enhanced, we study a set of six different management treatments describing a gradient from high impact to undisturbed succession to answer the following questions:

- Do we find differences in mycorrhizal infection rates between the six analysed management treatments?

- Is it possible to relate infection rates and the potential of the six treatments to preserve a stable vegetation composition?

- Thus, can we use mycorrhization rates for the evaluation of different management treatments with respect to nature conservation aims?

\section{Materials and methods}

\section{Study site}

The study was carried out at the grassland site St. Johann in SW Germany (Baden-Württemberg; $48.5^{\circ} \mathrm{N}, 9.4^{\circ} \mathrm{E}$, $760 \mathrm{~m}$ a.s.l.). The area is characterized by a mean annual temperature of approx. $6.0-6.5^{\circ} \mathrm{C}$, an average annual rainfall of about $1,000 \mathrm{~mm}$, and a growing season length of 165-172 days. Because of its location on the Swabian Alb the parent material for the rendzic leptosols is limestone of the White Jura (Schreiber et al. 1997; Schreiber et al. 2009a). The site is part of the fallowland experiments Baden-Württemberg (Schreiber 1977; Schreiber et al. 2009a). Following a period with extensive sheep-grazing, in 1975 the following management treatments were established and continuously applied until today: (1) mulching twice a year in June and late August (2 M), (2) mulching once a year in late August (1 M), (3) mulching every second year in late August (M2), (4) mowing with removal of the cut grass once a year in late August (1MO), (5) burning once a year outside the plant growing season (1B), and (6) undisturbed succession (S). The different management treatments were applied without replication on neighbouring plots of about $900 \mathrm{~m}^{2}(15 \times 60 \mathrm{~m})$ separated by a small buffer zone.

\section{Vegetation composition}

To describe the present vegetation composition, we used the results of a vegetation survey carried out in 2000 (which is the latest available vegetation data, Moog et al. 2002). The vegetation sampling was carried out on transects of eight $2 \times 2 \mathrm{~m}$ plots in the centre of each treatment plot, using the method of Braun-Blanquet (1964) with abundance classes following Schmidt (1974).
Soil sampling

Soil samples were taken in early spring 2005, air-dried ( 1 week at $20^{\circ} \mathrm{C}$ ), and sieved using a $2 \mathrm{~mm}$ sieve. In each treatment plot two soil samples were taken, consisting of 35 sub-samples to $8 \mathrm{~cm}$ depth. The sieved samples were analyzed for plant available phosphorus and plant available potassium contents using the ICP-OES (Jobin Yvon Ultima 2) following an extraction using the CAL method (calcium lactate); $\mathrm{pH}$ was determined on a 1:5 soil:0.01 $\mathrm{M} \mathrm{CaCl}_{2}$ suspension using a $\mathrm{pH}$ meter (glass electrode). An aliquot was ground with an ultracentrifugal mill, and total $\mathrm{C}$ and $\mathrm{N}$ of the ground soil were analyzed with a Euro EA 3000 (Euro Vector, Italy). Carbonate (IC) was analyzed conductometrically with a Wösthoff-apparatus (Wösthoff Messtechnik GmbH, Germany). Organic C (Corg) was calculated as the difference of total $\mathrm{C}$ and IC.

\section{Mycorrhiza}

In a pilot study, we detected three suitable species for our analyses as forming exclusively either ecto- or endomycorhiza (to reduce mistakes when estimating the degree of mycorrhization) and occurring frequently on all examined treatments (without a strong preference for one treatment): Brachypodium pinnatum (L.) P. Beauv. (Tor Grass), Helianthemum nummularium (L.) Mill. s. 1. (Common Rockrose) and Galium verum L. s. str. (Lady's Bedstraw or Yellow Bedstraw). We found that $H$. nummularium and $B$. pinnatum were forming endomycorrhiza (AM-arbuscular mycorrhiza) and $G$. verum ectomycorrhiza only in our study site, although $H$. nummularium and $G$. verum may form both kinds of mycorrhiza types.

Mycorrhizal infection rates were measured on 15 plants per species and management treatment. They were harvested every third meter along a $45 \mathrm{~m}$ transect on each treatment plot. In the field the roots of each single plant up to a depth of $15 \mathrm{~cm}$, representing one sample, were dug out, retained and stored in 50\% ethanol.

We stained the roots according to the method of Koske and Gemma (1989): Roots were washed and heated for $30 \mathrm{~min}$ in $2.5 \% \mathrm{KOH}$ at $90^{\circ} \mathrm{C}$ in a water bath for tissue clearing. After rinsing the roots in water, they were bleached in alkaline $\mathrm{H}_{2} \mathrm{O}_{2}$ for $20 \mathrm{~min}$. Because the tissues have to be acidic for good dye retention, the roots were acidified by soaking for at least $12 \mathrm{~h}$ in a $1 \% \mathrm{HCl}$ solution. The acidified roots were then heated in an acidic glycerol solution $\left(50 \%\right.$ glycerol, $\left.45 \% \mathrm{H}_{2} \mathrm{O}, 5 \% \mathrm{HCl}(1 \%)\right)$ containing $0.05 \%$ methylene blue (VWR) and at $90^{\circ} \mathrm{C}$ in a water bath for $30 \mathrm{~min}$. Finally they were stored in acidic glycerol solution to allow excess stain to leach from roots.

To estimate the degree of mycorrhization the stained roots were cut into segments of approximately $1 \mathrm{~cm}$ length. 
Per plant 10 randomly chosen root segments were mounted in a line on microscope slides with coverslips. Using a dissecting microscope at $40 \times$ magnification the slides were moved in vertical direction (Brundrett et al. 1994). Each time a root segment was hit, the degree of mycorrhization was estimated for the visible part of the root according to the following classes, based on which a mean degree of mycorrhization for each plant was calculated.

0 No infection (calculated as 0)

1 Less than $25 \%$ of the visible cells infected (calculated as $12.5 \%$ )

2 Between 25 and $50 \%$ of the visible cells infected (calculated as 37.5\%)

3 More than $50 \%$ of the visible cells infected (calculated as $75 \%$ )

Data analysis

To avoid overestimation of common species, species abundances were transformed following the formula $y=x^{0.25}$ (Wildi 1986) prior to multivariate vegetation analyses. Due to the unimodal structure of the analyzed data, a detrended correspondence analysis (DCA, Hill and Gauch 1980) was carried out to determine differences in vegetation composition between treatments. Plots and species abundances were ordinated and, to present a bi-plot, the degree of mycorrhization of the three study species correlated with the axes. Ordinations were performed with the program PcOrd 5.21 (McCune and Mefford 1999). All correlations between soil parameters and degrees of mycorrhization were tested for significance. As the number of vegetation relevées, soil samples and plant samples (degree of mycorrhization) differed, we first calculated the mean values for each treatment. Thus all correlation analyses were done with $N=6$. The degree of mycorrhization of each species was tested for differences between treatments by one-way ANOVA with subsequent post-hoc Scheffé-tests. If the criteria of normal distribution and homogeneous variances were not met, logtransformations were applied. All statistical tests were carried out with SPSS 12.5 (SPSS Inc.).

\section{Results}

The ordination of the vegetation relevées yielded distinct groups for the different management treatments (Fig. 1). The first axis explained approximately $60 \%$ of the variation within the dataset. Along the first axis we found from the right to the left the following sequence of management treatments: "mulching twice a year (2 M)", "mowing once a year (1 MO)", "mulching once a year (1M)", "mulching every second year (M2)", "burning once a year (1B)" and "natural succession $(\mathrm{S})$ ". Furthermore, the first axis was strongly correlated with the degrees of mycorrhization of

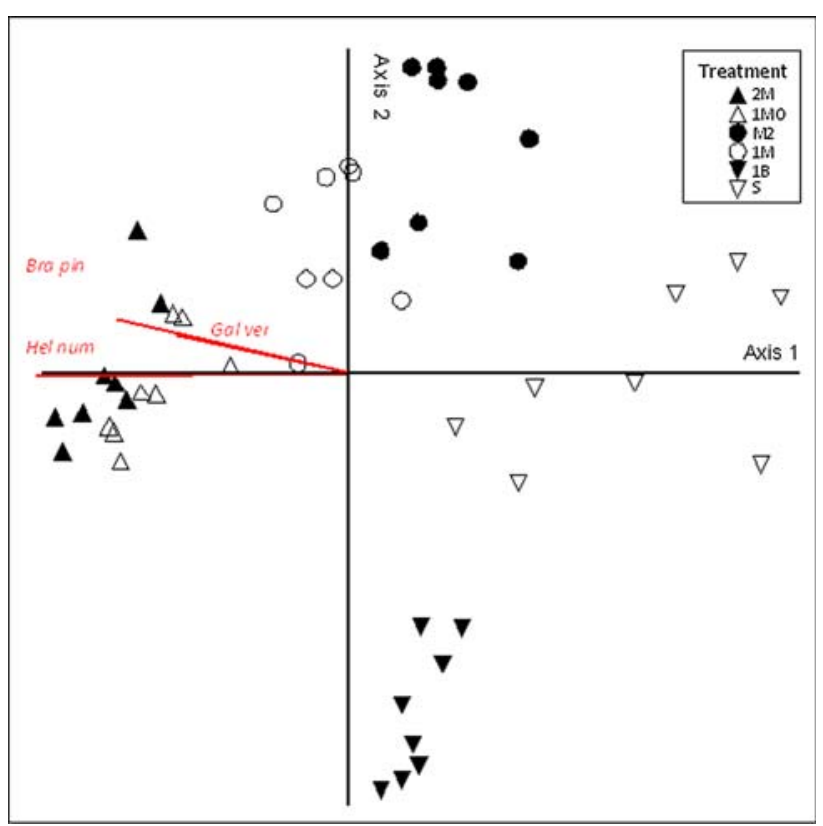

Fig. 1 Ordination diagram (DCA) of the vegetation relevées describing the vegetation composition of grassland plots with six different management treatments (abbreviations of the treatments see Table 2). Matrix: 91 species, 48 relevées (axis $1: r^{2}=0.58$, length of gradient $=2.14$; axis $2: r^{2}=0.09$ ); a bi-plot is presented with the degrees of mycorrhization of the three species studied (s. Table 1). Bra pin = Brachypodium pinnatum, Gal ver $=$ Galium verum and Hel num $=$ Helianthemum nummularium

Table 1 Test-values of the ANOVAs for differences between the degrees of mycorrhization (Mycor.), Pearson's correlation coefficients between degrees of mycorrhization and the first axis of the ordination presented in Fig. 1, and correlations between the degrees of mycorrhization and soil parameters

\begin{tabular}{|c|c|c|c|c|c|c|c|c|}
\hline & $\begin{array}{l}\text { Mycor. } \\
F \text {-value }\end{array}$ & $\begin{array}{l}\text { Axis } 1 \\
r\end{array}$ & $\begin{array}{l}\mathrm{C}_{\text {org }} \\
r\end{array}$ & $\begin{array}{l}\mathrm{N}_{\mathrm{t}} \\
r\end{array}$ & $\begin{array}{l}\mathrm{C} / \mathrm{N} \\
r\end{array}$ & $\begin{array}{l}\mathrm{P} \\
r\end{array}$ & $\begin{array}{l}\mathrm{K} \\
r\end{array}$ & $\begin{array}{l}\mathrm{pH} \\
r\end{array}$ \\
\hline Brachypodium pinnatum & $24.81^{* *}$ & $-0.831 *$ & $0.346^{\mathrm{ns}}$ & $0.415^{\mathrm{ns}}$ & $-0.063^{\mathrm{ns}}$ & $-0.664^{*}$ & $0.056^{\mathrm{ns}}$ & $-0.175^{\mathrm{n}}$ \\
\hline Galium verum & $7.35^{* *}$ & $-0.735^{\text {trend }}$ & $0.121^{\mathrm{ns}}$ & $0.180^{\mathrm{ns}}$ & $0.032^{\mathrm{ns}}$ & $-0.594^{*}$ & $-0.087^{\mathrm{ns}}$ & $-0.200^{\mathrm{n}}$ \\
\hline Helianthemum nummularium & $4.22^{\text {trend }}$ & $-0.975 * *$ & $0.186^{\mathrm{ns}}$ & $-0.005^{\mathrm{ns}}$ & $0.483^{\mathrm{ns}}$ & $-0.890 * * *$ & $0.122^{\mathrm{ns}}$ & $-0.280^{\mathrm{ns}}$ \\
\hline
\end{tabular}

All correlation analyses were performed with plot means $(N=6)$. Levels of significance are indicated as $* * * p$-value $\leq 0.001, * * p$-value $\leq 0.01$, $* p$-value $\leq 0.05$, and trend $p$-value $\leq 0.1$ 
Fig. 2 Degrees of mycorrhization for the species Brachypodium pinnatum, Galium verum and Helianthemum nummularium in grassland plots with six different management types (abbreviations of the treatments see Table 2). Means and standard errors of $N=15$ individuals per species and treatment (except for $B$. pinnatum with $N=10$ for $2 \mathrm{M}$, and $N=7$ for $1 \mathrm{MO}$, and $G$. verum with $N=11$ for $2 \mathrm{M}, N=13$ for $1 \mathrm{MO}$, and $N=14$ for M2, $1 \mathrm{M}$ and $1 \mathrm{~B}$ ); statistically significant differences are indicated by different letters

B. pinnatum, H. nummularium and G. verum (Fig. 1; Table 1).

For these three species we found significant differences in the degree of mycorrhization between the six treatments (Table 1). As shown in Fig. 2, the species differed in their absolute degree of mycorrhization, but for each species the degrees of mycorrhization decreased from mulching twice a year (2 M), mowing once a year (1 MO), mulching once a year (1M), mulching every second (M2) to burning once a year (1B) and natural succession (S).

In Table 2 the differences between the investigated soil parameters are presented: For $\mathrm{N}, \mathrm{C} / \mathrm{N}$ and the $\mathrm{pH}$-value we found only minor variations. $\mathrm{C}$ and $\mathrm{K}$ contents were lowest for the succession treatment. For phosphate, however, an increase from $1 \mathrm{MO}, 2 \mathrm{M}, 1 \mathrm{M}, \mathrm{M} 2$ to $1 \mathrm{~B}$ was observed; only for the succession treatment no phosphate was detected in the top soil. When testing for a relationship between the degree of mycorrhization and soil parameters, only phosphate showed significant correlations for all the investigated species (Table 1): with decreasing phosphate content of the soil, the degrees of mycorrhization increased. The only exception from this pattern was the succession treatment, which showed phosphate contents below the detection limit (Table 2), but also low degrees of mycorrhization (Fig. 2).

\section{Discussion}

The floristic composition on the plots with different management followed a clear pattern, related to a gradient in management intensity from mowing, followed by mulching twice a year, once a year, every second year, burning and undisturbed succession. This differentiation may be related to plant nutrient availability (Alard et al. 2005; Römermann et al. 2005; Schmidt 2006a), as mowing is assumed to lead to a loss of nutrients, whereas mulching every second year and succession are leading to an accumulation of litter and probably also of nutrients (Kahmen et al. 2002; Moog et al. 2002). Burning leads to advanced nutrient availability (principally phosphate) without litter accumulation (Schreiber et al. 2009b), but it is not well suited to conserve the initial vegetation composition (Kahmen et al. 2002; Jeschke et al. 2008). However, we did not find any relationship between management
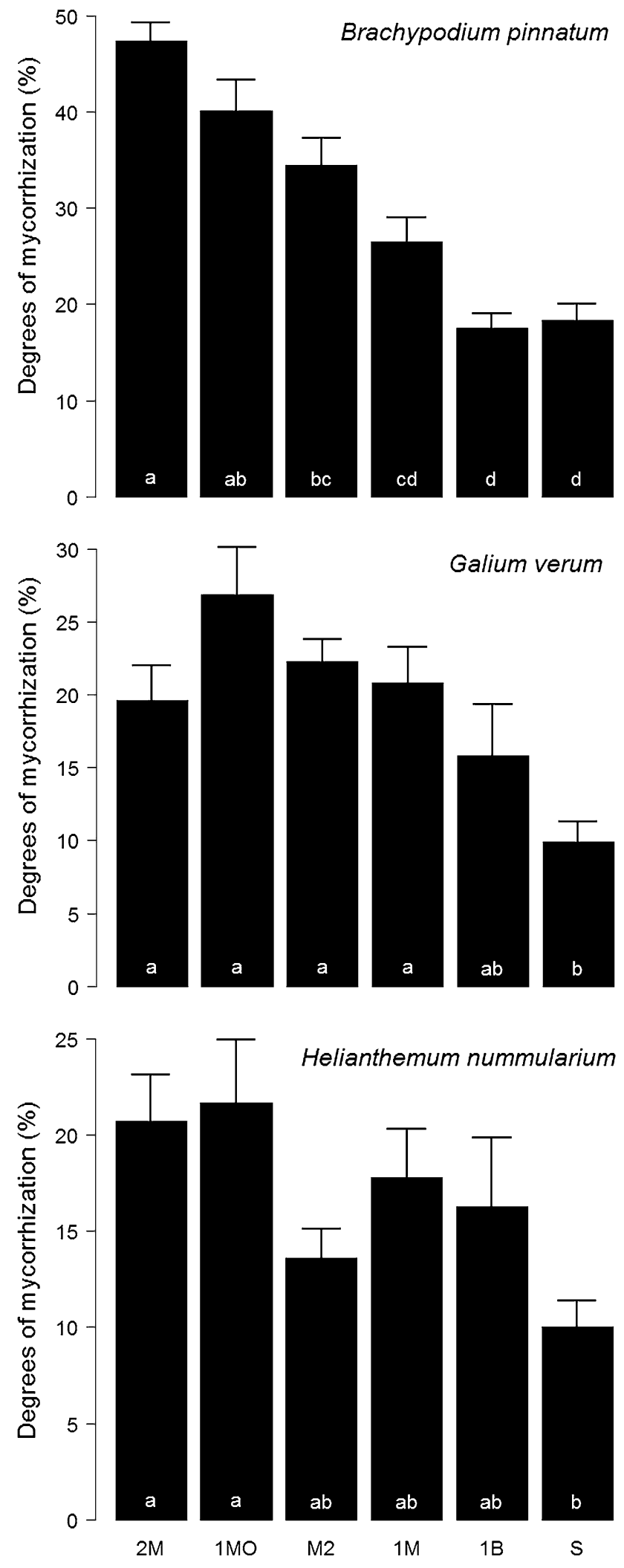

intensity and soil nitrogen content, whereas soil content of phosphate generally increased with management intensity (with the exception of the succession treatment). This is in 
Table 2 Organic carbon $\left(\mathrm{C}_{\mathrm{org}}\right)$, total nitrogen $\left(\mathrm{N}_{\mathrm{t}}\right), \mathrm{C} / \mathrm{N}$ ratio, plant available phosphorus $(\mathrm{P})$, plant available potassium $(\mathrm{K})$, and soil acidity $(\mathrm{pH})$ in the top soil of six grassland plots differing in management type (means; 0-8 cm soil depth) in 2005

\begin{tabular}{lllllll}
\hline Treatment & $\begin{array}{l}\mathrm{C}_{\text {org }} \\
(\mathrm{mg} / \mathrm{kg}\end{array}$ & $\begin{array}{c}\mathrm{N}_{\mathrm{t}} \\
\text { dry soil })\end{array}$ & $\begin{array}{l}\mathrm{C} / \mathrm{N} \\
\text { Ratio }\end{array}$ & $\begin{array}{l}\mathrm{P} \\
(\mathrm{mg} / \mathrm{kg}\end{array}$ & $\begin{array}{c}\mathrm{K} \\
\text { dry soil })\end{array}$ & $\begin{array}{l}\mathrm{pH} \\
\left(\mathrm{CaCl}_{2}\right)\end{array}$ \\
\hline $1 \mathrm{MO}$ & 74.9 & 6.4 & 11.8 & 4.4 & 49.8 & 5.51 \\
$2 \mathrm{M}$ & 77.6 & 6.5 & 11.9 & 4.4 & 62.7 & 5.74 \\
$1 \mathrm{M}$ & 75.5 & 6.2 & 12.0 & 5.4 & 68.5 & 5.41 \\
$\mathrm{M} 2$ & 76.0 & 6.6 & 11.5 & 9.0 & 52.3 & 5.96 \\
$1 \mathrm{~B}$ & 75.6 & 6.2 & 12.0 & 9.6 & 63.1 & 5.93 \\
S & 71.9 & 6.2 & 11.5 & b.1. & 46.9 & 5.65 \\
\hline
\end{tabular}

b.l., below detection limit; $2 \mathrm{M}$, mulching twice a year; $1 \mathrm{M}$, mulching once a year; M2, mulching every second year; 1MO, mowing with removal of the litter once a year; $1 \mathrm{~B}$, burning once a year; $\mathrm{S}$, undisturbed succession

accordance with several authors who stressed the importance of phosphate for vegetation development in semi-dry grasslands (Morecroft et al. 1994; Wilson et al. 1995; Grime et al. 2000; Köhler et al. 2001; Carroll et al. 2003). Due to ongoing nitrogen deposition in central Europe (Bobbink and Roelofs 1995), nitrogen does not seem to be the growth-limiting factor in calcareous grasslands any more (Willems et al. 1993; Neitzke 2001).

Nevertheless, in the current study we detected an absence of phosphate in the soil samples of the succession treatment. As already mentioned, succession results in increased litter accumulation (Kahmen et al. 2002; Moog et al. 2002), leading to reduced light availability at the soil surface (Bergelson 1990; Facelli and Pickett 1991), which inhibits low-growing species (Gaudet and Keddy 1988; Lavorel et al. 1999). Furthermore, when litter is accumulated, plant available nutrients in the soil increase after a period of immobilization in the litter (Bobbink and Willems 1993). Next to these processes, the absence of phosphate in the soil samples of the succession treatment may be due to the relocation of nutrients from photosynthetic active biomass to storage organs at the end of the growing season. This was described for B. pinnatum and other grassland species by Werner (1983), and is also well known for woody plants. In contrast to other management treatments, on the succession plot of our study site phosphate was bound in the vegetation (Werth et al. unpublished data); thus, relocation processes to soil nutrient pools are of minor importance (Werner 1983). As the initial vegetation composition and soil contents, the former management type (grazing) and deposition rates from the air were comparable for the whole study area (Schreiber 1977; Schiefer 1981), we conclude that the observed differences in plant available phosphate between treatments developed due to differences in nutrient removal and/or relocation. Management treatments and the availability of nutrients are both important factors influencing vegetation composition (Carroll et al. 2003; Bonanomi et al. 2006), but these cannot clearly be separated (Klimek et al. 2007).

The degrees of mycorrhization of the three investigated species in our study showed comparable pattern in relation to different management treatments, but strong differences in absolute values between species. As pointed out by Grime et al. (1987) and Köhler et al. (2001) principally AM is important for nutrient uptake by plants in calcareous grasslands; the competitive performance of single species thus depends on their ability to benefit from mycorrhiza (Streitwolf-Engel et al. 1997). Looking how individual plants of one species perform in different environments, the degrees of mycorrhization reflect the plant-available phosphate in soils (Titus and Leps 2000). However, comparing individuals from two different species growing under the same ecological conditions, the extent at which these are infected by mycorrhization is determined by their physiological ability to form mycorrhiza (Smith and Read 1997). Thus, when using mycorrhizal infection rates to compare environmental conditions in ecosystems, only the variation within species, but not differences between species can be interpreted and are ecologically meaningful. However, it may still be recommended to analyse more than one species: It is wellknown that different management treatments lead to differences in population structure (age-classes; Poschlod et al. 2009), with the consequence that in a given treatments species of one age-class might prevail. However, the fitness of individual plants, and therefore their ability to allow or suppress mycorrhizal infection may be affected by their age.

The results of the current study indicate that degrees of mycorrhization are related to management: treatments leading to nutrient removal (principally phosphate) showed a higher degree of mycorrhization compared to treatments leading to nutrient enrichment. Thus, it may be possible to evaluate the effects of management treatments for conserving calcareous grasslands based on the degree of mycorrhization. As all species in our study show comparable patterns, they support the following ranking of management treatments according their suitability to conserve the initial species composition: mowing is suitable best, second-best mulching (twice a year $\rightarrow$ once a year $\rightarrow$ every second year), followed by burning and undisturbed succession. While this ranking is consistent with the results of the vegetation analyses and soil contents of plant available phosphate, we may stress the potential of mycorrhizal infection rates for evaluating the suitability of management treatments for nutrient removal for grassland ecosystems. As stressed above, only for management treatments leading to litter accumulation, the degree of mycorrhization failed to be correlated with plant available phosphate.

From our study we conclude that mycorrhizal infection rates (1) can be used to evaluate different management 
treatments for their suitability to conserve the initial vegetation composition, and (2) may provide information about the processes of adaptation to the current management, namely to differences in plant availability phosphate. However, as discussed for the undisturbed succession treatment, it might not be sufficient to look at the degrees of mycorrhization only. These are related to phosphate availability, but it is impossible to detect nutrient-relocation processes within plants. Thus, to describe adaptation processes to different management treatments, the degree of mycorrhization should be analysed together with plantinternal nutrient relocation patterns.

Acknowledgments This work was funded by the LEL (Landesanstalt für Entwicklung der Landwirtschaft und der ländlichen Räume; Baden-Württemberg, Germany). We thank Wolfgang Schmidt, Christine Römermann, Bertil O. Krüsi and one anonymous reviewer for many useful comments on earlier drafts of the manuscript. The editor Sonja Wipf helped much to improve the quality of the manuscript.

Open Access This article is distributed under the terms of the Creative Commons Attribution Noncommercial License which permits any noncommercial use, distribution, and reproduction in any medium, provided the original author(s) and source are credited.

\section{References}

Alard D, Chabrerie O, Dutoit T, Roche P, Langlois E (2005) Patterns of secondary succession in calcareous grasslands: can we distinguish the influence of former land uses from present vegetation data? Basic Appl Ecol 6:161-173

Bergelson J (1990) Life after death-site preemption by the remains of Poa аппиа. Ecology 71:2157-2165

Bobbink R, Roelofs JGM (1995) Nitrogen critical loads for natural and semi-natural ecosystems: the empirical approach. Water Air Soil Pollut 85:2413-2418

Bobbink R, Willems JH (1993) Restoration management of abandoned chalk grassland in the Netherlands. Biodivers Conserv 2:616-626

Bohn U, Neuhäusl R (2004) Map of the natural vegetation of Europe. Scale 1:2500000. Explanatory Text, Legend, Maps. Bundesamt für Naturschutz, Bonn-Bad Godesberg

Bonanomi G, Caporaso S, Allegrezza M (2006) Short-term effects of nitrogen enrichment, litter removal and cutting on a Mediterranean grassland. Acta Oecol 30:419-425

Braun-Blanquet J (1964) Pflanzensoziologie - Grundzüge der Vegetationskunde. Springer, Wien

Brundrett M, Melville L, Peterson L (1994) Practical methods in mycorrhiza research. Mycologue Publications, Waterloo www. mycolog.com

Carroll JA, Caporn SJM, Johnson D, Morecroft MD, Lee JA (2003) The interactions between plant growth, vegetation structure and soil processes in semi-natural acidic and calcareous grasslands receiving long-term inputs of simulated pollutant nitrogen deposition. Environ Pollut 121:363-376

Facelli JM, Pickett STA (1991) Plant litter-its dynamics and effects on plant community structure. Bot Rev 57:1-32

Garcia A (1992) Conserving the species-rich meadows of Europe. Agric Ecosyst Environ 40:219-232
Gaudet CL, Keddy PA (1988) A comparative approach to predicting competitive ability from plant traits. Nature 334:242-243

Grime JP, Mackey JML, Hillier SH, Read DJ (1987) Floristic diversity in a model system using experimental microcosms. Nature 328:420-422

Grime JP, Brown VK, Thompson K, Masters GJ, Hillier SH, Clarke IP, Askew AP, Corker D, Kielty JP (2000) The response of two contrasting limestone grasslands to simulated climate change. Science 289:762-765

Hill MO, Gauch HG (1980) Detrended correspondence analysis: an improved ordination technique. Vegetatio 42:47-58

Jeschke M, Kiehl K, Pfadenhauer J, Gigon A (2008) Langfristige Auswirkungen ehemaliger Bewirtschaftungsvarianten auf die Diversität von Blütenpflanzen, Moosen und Flechten eines Kalkmagerrasens. Bot Helv 118:95-109

Kahmen S (2004) Plant trait responses to grassland management and succession. Diss Bot 382:1-122

Kahmen S, Poschlod P, Schreiber K-F (2002) Conservation management of calcareous grasslands. Changes in plant species composition and response of functional traits during 25 years. Biol Conserv 104:319-328

Kleijn D, Sutherland WJ (2003) How effective are European agrienvironment schemes in conserving and promoting biodiversity? J Appl Ecol 40:947-969

Klimek S, Richter AGK, Hofmann M, Isselstein J (2007) Plant species richness and composition in managed grasslands: the relative importance of field management and environmental factors. Biol Conserv 134:559-570

Köhler B, Ryser P, Güsewell S, Gigon A (2001) Nutrient availability and limitation in traditionally mown and in abandoned limestone grasslands: a bioassay experiment. Plant Soil 230:323-332

Koide RT (1991) Nutrient supply, nutrient demand and plant response to mycorrhizal infection. New Phytol 117:365-386

Koske RE, Gemma JN (1989) A modified procedure for staining roots to detect VA mycorrhizas. Mycol Res 92:486-505

Küster HJ (1996) Geschichte der Landschaft in Mitteleuropa. Von der Eiszeit bis zur Gegenwart. C.H. Beck, München

Lavorel S, Rochette C, Lebreton JD (1999) Functional groups for response to disturbance in Mediterranean old fields. Oikos 84:480-498

Lorenzo M, Michele S, Sebastian K, Johannes I, Angelo P (2007) Effects of local factors on plant species richness and composition of Alpine meadows. Agric Ecosyst Environ 119:281-288

Mccune B, Mefford MJ (1999) PC-ORD. Multivariate analysis of ecological data, Version 4. MjM Software Design, Gleneden Beach, Oregon

Moog D, Poschlod P, Kahmen S, Schreiber K-F (2002) Comparison of species composition between different grassland management treatments after 25 years. Appl Veg Sci 5:99-106

Morecroft MD, Sellers EK, Lee JA (1994) An experimental investigation into the effects of atmospheric nitrogen deposition on two seminatural grasslands. J Ecol 82:475-483

Mullen RB, Schmidt SK (1993) Mycorrhizal infection, phoshorus uptake, and phenology in Ranunculus adoneus: implications for the functioning of mycorrhizae in alpine systems. Oecologia 94:229-234

Myklestad A (2004) Soil, site and management components of variation in species composition of agricultural grasslands in western Norway. Grass Forage Sci 59:136-143

Neitzke M (2001) Analysis of vegetation and nutrient supply in calcareous grassland border zones to determine critical loads for nitrogen. Flora 196:292-303

Poschlod P, WallisDeVries MF (2002) The historical and socioeconomic perspective of calcareous grasslands-lessons from the distant and recent past. Biol Conserv 104:361-376 
Poschlod P, Bakker JP, Kahmen S (2005) Changing land use and its impact on biodiversity. Basic Appl Ecol 6:93-98

Poschlod P, Bernhardt-Römermann M, Donaubauer T, Hoffmann J, Sittig E (2009) Die Altersstruktur von Pflanzenpopulationen ein naturschutzfachliches Bewertungskriterium. In: Schreiber K-F, Brauckmann H-J, Broll G, Krebs S, Poschlod P (Hrsg.) Artenreiches Grünland in der Kulturlandschaft. 35 Jahre Offenhaltungsversuche Baden-Württemberg. Naturschutz - Spectrum Themen 97:289-299

Quétier F, Lavorel S, Thuiller W, Davies I (2007) Plant-trait-based modelling assessment of ecosystem-service sensitivity to landuse change. Ecol Appl 17:2377-2386

Römermann C, Dutoit T, Poschlod P, Buisson E (2005) Influence of former cultivation on the unique Mediterranean steppe of France and consequences for conservation management. Biol Conserv 121:21-33

Römermann C, Bernhardt-Römermann M, Kleyer M, Klimesová J, Poschlod P (in press) Substitutes for grazing in semi-natural grasslands-represent mowing or mulching valuable alternatives to maintain vegetation dynamics? J Veg Sci. doi:10.1111/ j.1654-1103.2009.01106.x

Schiefer J (1981) Bracheversuche Baden-Württemberg. Vegetationsund Standortsentwicklung auf 16 verschiedenen Versuchsflächen mit unterschiedlichen Behandlungen. Beihefte zu den Veröffentlichungen für Naturschutz und Landschaftspflege in BadenWürttemberg 22:1-325

Schmidt W (1974) Die vegetationskundliche Untersuchung von Dauerprobeflächen. Mitt Florist-soziol Arb-gem 17:103-106

Schmidt W (2006a) Biodiversity and plant productivity in a grassland succession: effects of nutrient levels and disturbance regimes. Pol Bot Stud 22:437-448

Schmidt W (2006b) Temporal variation in beech masting (Fagus sylvatica L.) in a limestone beech forest (1981-2004). Allg Forst Jagdztg 177:9-19

Schreiber K-F (1977) Zur Sukzession und Flächenfreihaltung auf Brachland in Baden-Württemberg. Verh Ges Ökol 5:251-263

Schreiber K-F (1995) Renaturierung im Grünland - Erfahrungen aus langjährigen Untersuchungen und Managementmaßnahmen. Ber Reinhold-Tüxen-Ges 7:111-139

Schreiber K-F, Broll G, Braukmann H-J (1997) Vegetationskundliche, bodenökologische und faunistische Untersuchungen auf den
Bracheversuchsflächen in Baden-Württemberg - eine Bilanz nach über 20 Jahren. Veröffentlichungen Projekt „Angewandte Ökologie" (PAÖ) 22:49-68

Schreiber K-F, Brauckmann H-J, Broll G, Krebs S, Poschlod P (2009a) Artenreiches Grünland in der Kulturlandschaft. 35 Jahre Offenhaltungsversuche Baden-Württemberg. Naturschutz Spectrum Themen 97

Schreiber K-F, Drobnik J, Poschlod P (2009b) Das Kontrollierte Brennen als Pflegemaßnahme von Grünlandbrachen. Forstarchiv 80:265-279

Smith SE, Read DJ (1997) Mycorrhizal symbiosis. Academic Press, San Diego

Streitwolf-Engel R, Boller T, Wiemken A, Sanders IR (1997) Clonal growth traits of two Prunella species are determined by co-occurring arbuscular mycorrhizal fungi from a calcareous grassland. J Ecol 85:181-191

Titus JH, Leps J (2000) The response of arbuscular mycorrhizae to fertilization, mowing, and removal of dominant species in a diverse oligotrophic wet meadow. Am J Bot 87:392-401

WallisDeVries MF, Poschlod P, Willems JH (2002) Challenges for the conservation of calcareous grasslands in northwestern Europe: integrating the requirements of flora and fauna. Biol Conserv 104:265-273

Watkinson AR, Ormerod SJ (2001) Grasslands, grazing and biodiversity: editors' introduction. J Appl Ecol 38:233-237

Werner W (1983) Untersuchungen zum Stickstoffhaushalt einiger Pflanzenbestände. Scr Geobot 16:1-95

Werth M, Brauckmann H-J, Broll G, Schreiber K-F (2005) Analysis and simulation of soil organic-carbon stocks in grassland ecosystems in SW Germany. J Plant Nutr Soil Sci 168:472-482

Wildi O (1986) Analyse vegetationskundlicher Daten. Veröff Geobot Inst Eidgenöss Tech Hochsch Stift Rübel Zür 1-90

Willems JH, Peet RK, Bik L (1993) Changes in chalk-grassland structure and species richness resulting from selective nutrient additions. J Veg Sci 4:203-212

Wilson EJ, Wells TCE, Sparks TH (1995) Are calcareous grasslands in the UK under threat from nitrogen deposition? An experimental determination of a critical load. J Ecol 83:823-832 